\title{
Exploring Different Perspectives on Limitations and Promises of Service-Learning as an Innovative Pedagogy: Review of Literature
}

\author{
${ }^{1}$ Hamdan Said \\ 1lqbal Ahmad \\ 'Syed Shafeq Syed Mansor \\ 2Zubaidah Awang \\ ${ }^{1}$ Faculty of Education, Universiti Teknologi Malaysia, 2Language Academy, Universiti Teknologi Malaysia \\ p-hamdan@utm.my,shahnavi777@hotmail.com,p-shafeq@utm.my,m-zu@utm.my
}

\section{Doi:10.5901/mjss.2015.v6n4s1p311}

\begin{abstract}
In the last two decades service-learning has become very popular as an innovative educational approach all over the world. Studies have reported that as an innovative and distinct instructional method it benefits both students and communities alike. However, despite of this, its effectiveness as an educational practice is still debated. This paper investigates into this gap in the current service-learning literature. The paper has two aims. First, to answer the questions that how service-learning is a distinct innovative pedagogy and why its effectiveness is still questioned. Second, to explore the challenges that it faces and opportunities it provides. The review reveals that although service-learning is different from traditional methods, its position as effective method is still opposed by many quarters. A small number of researchers consider it as a time-consuming and expensive practice. However, the larger group holds the view that service-learning is effective and reciprocal method. On the basis of this review, this paper concludes that as an innovative pedagogy, service-learning achieves two aims: community receives service and students get learning. This characteristic makes it a distinctly unique educative method.
\end{abstract}

Keywords: Service-learning, pedagogy, challenges and opportunities, reciprocity

\section{Introduction}

Service-learning is an innovative reciprocal method that connects theory with practice and classroom with society. However, researchers are still divided among themselves upon the nature, aims and promises of service-learning as an innovative educational method. More specifically, despite its fast popularity as an innovative pedagogy, the birth and the growth of service-learning still lies in controversies (Giles \& Eyler, 1994). The origination of service-learning is rooted in experiential learning theories. However, more formally, theoretically, service-learning is associated with the progressive era in education which was mostly influenced by the theories of Addams, Dewey and Dorothy day (Dale \& Drake, 2005; Metcalf, 2010). However, as an innovative pedagogy, it appeared and became very popular in literature in late 90s and continues till now (Speck, 2001).

The origin of the term service-learning goes back to the fifties decade as well as the educational projects for linking social and political controversies of 1960s and 1970s (Bringle \& Hatcher, 1996; Furco, 2002a). Furthermore, even some of the famous professional organizations in America are associated with the concept of service-learning directly or indirectly. These organizations are contributing towards the promotion and development of the concept of servicelearning. Among those famous organizations is National Society for Experiential Education (NSEE) and Campus Outreach Opportunity League (COOL). These organizations positively propagated the concept of service-learning and became active in building a more just society (Campus Compact, 1999). Since its foundation, one of the major aims of service-learning has been community engagement (Stott \& Jackson, 2005). However, later on in 1970s it was discovered that along with community development, service-learning also played a great role in student learning and development. This realization created awareness among the circles of researchers about the unique position of service-learning as an innovative pedagogy. Thus, it was termed as a reciprocal in nature. Meaning that on one hand, it benefited both the community and students alike (Morgan \& Streb, 2001).

Researchers identified the nature of service-learning with regard to its academic and non-academic role (Billig, 
2004). This period also accepted the reciprocal nature of service-learning. Moreover, the later period further cemented the understanding of scholars regarding the uniqueness of service-learning as a pedagogical approach as compared to other methods (Giles \& Eyler, 1994). To further clarify the concept, researchers argue that it is a unique educative method, because on one hand, it prepares students for their academic growth and on the other hand, it provides service to the community being served. Many researchers have endorsed this that when conceptualized in this way, servicelearning is a pedagogical model that intentionally integrates academic learning and community service (Rhoads \& Howard, 1998; Bridgland, Dilulio \& Wulsin, 2008). There are growing evidences that service-learning strengthens students' academic learning and also enhances their higher thinking, critical thinking and problem solving skills as active citizens (Eyler \& Giles, 1999; Burnett, Long \& Home, 2005).

\section{Nature of Service-learning}

Many studies have termed service-learning as an important initiative for the academic, citizenship and social development of students (Kaye, 2004; Burnett et al., 2005; Baggerly, 2006; Goodman \& West-Olatunji, 2007). Servicelearning is different from community service or volunteerism. The true nature of service-learning is that it is a unique pedagogy because it stresses on reciprocity in learning and practice rather than theory (Kaye, 2004; Burnett et al., 2005). The term service-learning is defined as a credit bearing educational experience in which students: (a) participate in an organized service-activity that meets identified human and community needs; (b) reflect and reciprocate on the service activity in such a way to gain further understanding of course content, and broader appreciation of the discipline; and (c) an enhanced sense of personal values and civic responsibility (Bringle \& Hatcher, 1996).

Service-learning is an activity that connects service in the community with learning. It provides hands on experience to the students to apply newly learned knowledge and skills in real life situations to identify community needs and develop mechanisms to solve those problems which are not possible in the cases of many learning techniques or pedagogies (Pritchard\& Whitehead, 2004). Thus, service-learning combines service objectives with students' learning objectives. So the main aim in service-learning is that of learning not service. As stated above, that another unique aspect of service-learning is that as pedagogy it benefits both the students and the community where the service activity is conducted (Howard, 1998).

The process of service-learning is characterized by self-reflection, self-discovery and acquisition of values, skills and knowledge through experience rather than rhetoric. This nature of service-learning makes it a distinct teaching and learning approach which has invited many problems with regard to its universality and suitability as an effective educational practice (Burnett, Hamel, \& Long, 2004). Students who are practically involved in service-learning activities have ample opportunities to develop collaborative and empowering relationships with their communities which is rarely possible with more traditional teaching methodologies such as lecture method or dictation (Kaye, 2004; Goodman \& West-Olatunji, 2007).

As pedagogy, service-learning provides many benefits to students in the areas such as curriculum development, professional skills enhancement and personal growth (Burnett et al., 2005; Murray, Lampinen \& Kelly-Soderholm, 2006). These writers further say that the benefits of service-learning are not limited to students, rather, education centres such as schools, colleges and universities may also benefit from service-learning through various initiatives like community outreach, improvement of school, college or university curriculum, response to community needs, identifying employer needs and so on. Similarly, communities also reap the benefits of service-learning in the form of service-delivery and developing future citizens which ultimately serve the society as useful individuals.

\section{Limitations of Service-learning}

Service-learning has long been facing a number of problems. One of the acute problems is that of lack of commonly accepted definition. In the last two decades, more than hundred definitions of service-learning were presented (Furco, 2002b). This situation has created confusions among educators about the potential of service-learning as an effective pedagogy (Jacoby \& Associates, 1996).

The second problem is that service-learning has been mistakenly used interchangeably for volunteerism, internship and charity. This has created frustration among educators and researchers about its definition. Some have defined service-learning connection of community service with academic study to enrich learning, teach civic responsibility and strengthen communities (Fiske, 2001; Pritchard \& Whitehead, 2004). Research has also indicated that service-learning is a useful activity for students to demonstrate their abilities in a real life context. The application of knowledge, skills, critical thinking and judgment in real world situation also helps meet varying social needs of the communities in which they live 
(Wren, 2004).

In reality, service-learning is a distinct innovative pedagogy. It differs both from volunteerism, charity and community service. It is an experiential learning approach which is based on learning as its main purpose rather than service. However, it is unique because it provides benefits both to the community that receives the service and the students who perform the service. Hence, by nature it is collaborative and interactive. The focus of service-learning is to produce academic and civic outcomes (Furco, 2002a).

Defining service-learning is a bit difficult as it takes different forms under different conditions. It has been explained as a strategy, programme, philosophy and pedagogy (Root \& Billig, 2008). In view of many researchers, service-learning is both a philosophy, pedagogy and a strategy (Myers-Lipton, 1996; Moore, 2000; Lemieux \& Allen, 2007). For more elaboration, as a philosophy and pedagogy it promotes civic development of students, because service-learning is based upon the integration of community service and academic content. As a strategy, service-learning develops skills of students with the help of which they solve problems in the community and strengthen their connections with others such as community organizations and groups (Ramaley, 2000; Strage, 2000; Fenzel \& Peyrot, 2005; Lemieux \& Allen, 2007). Although, service-learning has a rich history in the literature, there is unanimity among researchers and universally accepted definition of service-learning. According to Govekar and Rishi (2007), service-learning is an educational approach that connects community service-learning with credit bearing academic experience. Strupeck and Whitten (2004) defined service-learning to be a form of active learning that provides students hands on learning experience.

Rama, Ravenscroft, Wolcott, and Zlotkowski (2000) pointed out that one of the problems regarding adopting a universally accepted definition of service-learning is due to the wide variety of service-learning programmes and projects that exist. Some of the service-learning projects are highly structured and long term while others are short term such as single day of service (Grovekar \& Rishi, 2007; Rama et al., 2000; Strupeck \& Whitten, 2004; Warburton \& Smith, 2003). Service-learning as an educational method that combines service objectives with learning objectives. The main intent is to benefit both the service provider and the receiver. The service experience enriches students' learning, develops civic responsibility, sense of collaboration, self-discover, self-reflection and acquisition of opportunities to promote values, skills and knowledge content (Gelmon, 2001; Seifer, 2005).

Despite of the variety of service-learning activities, all types of service-learning have the following four main components in common: (1) credit bearing, (2) community service, (3) structured reflection, (4) collaboration and reciprocity (Rama et al., 2000). The definition provided by Bringle and Hatcher (1995) seems well suited as it incorporates the four components of service-learning. Bringle and Hactcher (1995) defined service-learning to be a credit bearing teaching and learning pedagogy in which students (a) actively participate in an organized service activity in the community that satisfies community needs that promotes civic development of students, (b) critically think on the service activity that helps in better learning and understanding of the course content, and (c) work in collaboration during the service activity that helps in developing better sense of teamwork and sense of civic responsibility. Stukas, Worth, Clary and Synder (2009) stated that there is a difference between volunteer work and service-learning. In volunteer work, the volunteers offer their services free of charge to the recipients. The main purpose is social service not learning. However, in service-learning, the main focus is on learning rather than on service.

There are several issues and limitations that hinder the design, implementation and sustainability of servicelearning. These issues include inadequate beneficiary involvement, lack of training, lack of finance, pedagogical concerns, institutional and physical concerns, lack of assessment and negative attitude towards service-learning (Bringle, Hatcher \& Muthiah, 2010). For example, in another study Egger (2008) proposed mixing community service with students' learning is not encouraging. He argued that it is time wasting as well as of valuable resources because it actually promotes a communitarian anti individualistic social agenda. Studies by Svoboda Bak (2012) and Einfeild and Collins (2008) found that participation in service-learning helps students in enhancing civic skills, increasing community commitments, promoting democratic values and developing them into valuable citizens.

Butin (2003) discussed the issues related to authentic assessment in service-learning due to the complicated processes involved in it. Quezada and Christopherson (2005) found certain assessment mechanisms missing to evaluate the outcomes related to participation in service-learning. There are no assessments of many service-projects. One of the reasons is that most of the teachers have less orientation about how to assess or they have to wait until the servicelearning activity or project is completed. It is thus time consuming and the academic session is over by that time (Arenas, Bosworth \& Kwandayi, 2006). On the other hand, Chickering (2008) argued that service-learning is useful. It has academic, moral and social benefits attached to it.

Service-learning is important educational programme to serve people. But there are many obstacles involved in the process of performing the service. There are many social, moral, ethical and political issues of modern education that could be solved with the help of effective service-learning programmes (Kenan, 2009). Research has found many that 
service-learning promotes students interpersonal development, community connection, career development and problem solving skills. It is a practical pedagogical tool that positively develops students' attitude toward diversity and beliefs in self-efficacy (Ethridge, 2006; Lawrence \& Butler, 2010). Service-learning increases the abilities of students to perform personal and civic responsibilities more effectively (Ottenritter, 2004; Kielsmeier, Schultz \& Leeper, 2008).

Despite of the pressures on service-learning, researchers argued that it is a powerful pedagogy to promote students' civic development through community exposure (Simons \& Cleary, 2006). Simons and Cleary (2006) further explain that even though students can get enough academic knowledge from the traditional classroom, service-learning provides them with wider opportunities to learn beyond the bounds of the traditional classroom.

A study by Quezada and Christopherson (2005) reported many positive outcomes of service-learning such as increased confidence, patience, tolerance and improved leadership skills. Brown (2001) conducted a phenomenological study of high school students after their participation in a service-learning project. The results revealed an increased empathy for each other and long life desire for volunteerism. In another study, Diambra, McClam, Fuss, Burton and Fudge (2009) analysed perceptions of students after their participation in a service-learning project. The findings of the study showed that students recognized their unique roles in the service-learning activities as they had developed increased social skills, positive expectations of each other.

\section{Promises of Service-learning}

Basically service-learning is an engaged learning (Ehrlich, 1995; Goodman \& West-Olatunji, 2002). Students who participate in service-learning activities benefit in a number of ways. They develop caring and responsible attitudes toward community needs and their own duties (Eyler \& Giles, 1999). Studies have reported that service-learning increases students' sense of self-efficacy enhances their problem solving skills, ability to work in teams and planning skills (Rhoads \& Howard, 1998; Arman \& Scherer, 2002). As an academic pedagogy, service-learning develops important life skills of students such as effective communication, leadership, problem-solving and critical thinking skills. These skills are considered essential by many researchers for employability in the present job competitive market. All this becomes possible by integrating family, school and community efforts to the above mentioned larger aims of education (Murray et al., 2006).

One of the essential elements in the service-learning process is the community. Structuring quality service-learning activities helps the educational institutions to identify the needs and problems of the communities and mitigate them through building positive partnerships with schools, colleges and universities (Eyler \& Giles, 1999). In this way, communities see the youth as resources, not problems. This partnership will create a new generation of caring, experienced, active and committed citizens for the society (Boyte \& Harr, 1997).

By integrating the core elements of service-learning, all stake holders such as community, students, teachers and organizations will collectively reap the above mentioned benefits (Markus, Howard \& King, 1993). In the recent past, some of writers have reported that despite of the popularity of service-learning as an effective instructional tool to achieve some of the sublime aims of education such as development of active and responsible citizens, preparing leaders for future and effective contributing society members, service-learning based learning did not receive the kind of public attention (Kaye, 2004; Baggerly, 2006). However, in spite of this public apathy, service-learning offers wider opportunities of gains to society, young people and organizations (Burnett et al., 2005).

Schools are not the only institutions where the young people are educated. Community based organizations can also provide a more practical learning environment to the students than the traditional classrooms for their educational development (Honnet-Porter \& Poulsen, 1989). Learning in the community is open, critical and reciprocal. Students develop better learning skills and knowledge through personal exploration rather than external feeding (Shumer \& Duckenfield, 2004). Service-learning as an experiential educational practice best achieves this goal (Burnett et al., 2004). Psychologists also agree that learning is a constructive process which the individual reconstructs his/her new knowledge on the basis of the past experiences. People learn better through interaction and experience than by passive listening (Dewey, 1938; Bandura, 1977; Kolb, 1984).

\section{Conclusion}

On the basis of this review, the paper concludes that service-learning has become a popular pedagogy. It is continuously growing in popularity as an active and innovative learning practice. The review found that being a reciprocal method it is unique because it equally benefits both students and the communities. Moreover, the review revealed that servicelearning effectively integrates the concept of service with learning. This characteristic makes it a distinct and innovative 
pedagogy in many respects. As a result, the community receives the service and the students get the opportunity for learning. On the other hand, the review also interestingly discovered that service-learning is a more expensive method.

Writers believe that it cannot be easily incorporated and integrated in everywhere. It is resource demanding and time consuming as well. In many parts of the world, it cannot be practiced due to many restrictions and academic compulsions such as need of student preparation, lack of resources and lack of professional training in service-learning as well as poor assessment practices on how to assess service-learning performances of students. However, despite much opposition, service-learning is supported by many that it is a useful educational method that achieves many cherished goals of education more effectively. Among these service to the society and student learning are more prominent goals. Service-learning method achieves these two goals more effectively.

\section{Future Research}

This study explored some of the benefits of and challenges to service-learning. However, future research may investigate into other important areas as the immediate outcomes of service-learning such as effect of service-learning on listening skills, professional development of teachers, community development and so on, which will provide deeper understanding to the researchers regarding the effect of service-learning as an innovative approach in education.

\section{References}

Arenas, A., Bosworth, K., \& Kwandayi, H. P. (2006). Civic service through schools: An international perspective. Compare, 36(1), 23-40.

Arman, J. F., \& Scherer, D. (2002). Service learning in school counsellor preparation: A qualitative analysis. Journal of Humanistic Counselling, Education and Development, 41(1), 69-86.

Baggerly, J. (2006). Service learning with children affected by poverty: Facilitating multicultural competence in counselling education students. Journal of Multicultural Counselling and Development, 34(4), 244-255.

Bandura, A. (1977). Social learning theory. Eaglewood Cliffs. NJ: Prentice Hall.

Billig, S. H. (2004). Heads, hearts, and hands: The research on K-12 service-learning. In J. Kielsmeier, M. Neal, \& M. McKinnon (Eds.), Growing to greatness 2004 (pp. 12-25). St. Paul, MN: National Youth Leadership Council.

Boyte, H. \& Farr, H. (1997). The work of citizenship and the problem of service-learning. In R. Battistoni \& W. Hudson (Eds.), Experiencing citizenship: Concepts and models for service-learning in political science (pp. 35-48). Washington, DC: American Association for Higher Education.

Bridgeland, J. M., Dilulio, J. J., \& Wulsin, S. C. (2008). Engaged for success: Service-learning as a tool for high school dropout prevention. Washington, DC: Civic Enterprises.

Bringle, R. G. \& Hatcher, J. A. (1996). Implementing service-learning in higher education. Journal of Higher Education, 67(2), 221-239.

Bringle, R. G., \& Hatcher, J. A. (1995). A service-learning curriculum for faculty. Michigan Journal of Community Service-Learning, 2(1), $112-122$.

Bringle, R. G., Hatcher, J. A., \& Muthiah, R. N. (2010). The role of service-learning on the retention of first-year students to second year. Michigan Journal of Community Service-Learning, 16(2), 38-49.

Brown, D. M. (2001). Pulling it together: A method for developing service-learning and community partnerships based in critical pedagogy. Washington, DC: Corporation for National Service.

Burnett, J. A., Hamel, D., \& Long, L. L. (2004). Service learning in graduate counsellor education: Developing multicultural counselling competency. Journal of Multicultural Counselling and Development, 32(3), 180-191.

Burnett, J. A., Long, L. L., \& Horne, H. L. (2005). Service learning for counsellors: Integrating education, training, and the community. Journal of Humanistic Counselling, Education, and Development, 44(2), 158-167.

Butin, D. W. (2003). Of what use is it? Multiple conceptualizations of service-learning in education. Teachers College Record, 105(9), 1674-1692.

Campus Compact. (1999). Higher education in service to the nation. Providence, Rl: Campus Compact.

Chickering, A. (2008). Strengthening democracy and personal development through community engagement. In SC Reed \& C. Marienau (Eds.), Linking adults with community: Promoting civic engagement through community based learning: New directions for adult and continuing education. San Francisco, CA: Jossey-Bass.

Dale, P. \& Drake, T. (2005). Connecting academic and student affairs to enhance student learning success. New Directions for Community Colleges, 2005(131), 51-64.

Dewey, J. (1938). Experience and education. New York, NY: Collier Books.

Diambra, J. F., McClam, T., Burton, B., Fuss, A., \& Fudge, D. L. (2009). Using a focus group to analyze student's perceptions of a service-learning project. The College Student Journal, 43(1), 114-122.

Egger, J. (2008). No service to learning: Service-learning reappraised. Academic Questions, 21(2), 183-194.

Ehrlich, T. (1995). Taking service seriously. American Association of Higher Education Bulletin, 47(7), 8-10.

Einfeld, A., \& Collins, D. (2008). The relationships between service-learning, social justice, multicultural competence, and civic engagement. Journal of College Student Development, 49(2), 95-109. 
Ethridge, E. (2006). Teacher modelling of active citizenship via service-learning in teacher education. Mentoring \& Tutoring, 14(1), 49-65.

Eyler, J., \& Giles, D. E. (1999). Where's the learning in service-learning? San Francisco, CA: Jossey-Bass.

Fenzel, L. M., \& Peyrot, M. (2005). Comparing college community participation and future service behaviors and attitudes. Michigan Journal of Community Service Learning, 12(1), 23-31.

Fiske, E. B. (2001). Learning in deed: The power of service-learning for American schools. Battle Creek, Ml: W. K. Kellogg Foundation.

Furco, A. (2002a). Institutionalizing service-learning in higher education. Journal of Public Affairs, 6(Suppl. 1), 39-67.

Furco, A. (2002b). Is service-learning really better than community service? A study of high school service program outcomes. In A. Furco and S.H. Billig (Eds), Service-learning: The essence of pedagogy. Greenwich, CT: Information Age Publishing.

Gelmon, S. B. (2001). Assessing service-learning and civic engagement: Principles and techniques. Campus Compact.

Giles, D. E., \& Eyler, J. (1994). The theoretical roots of service-learning in John Dewey: Toward a theory of service-learning. Michigan Journal of Community Service-Learning, 1(1), 77-85.

Goodman, R. D., \& West-Olatunji, C. A. (2007). Social justice and advocacy training for counsellors: Using outreach to achieve praxis. Retrieved on October 10, 2014, from http://eric.ed.gov/ ERICDocs/data/ericdocs2sql/content_storage_01/0000019b/80 $12 \mathrm{a} / 74 / 3 c . p d f$

Govekar, M. A., \& Rishi, M. (2007). Service learning: Bringing real-world education into the b-school classroom. Journal of Education for Business, 83(1), 3-10.

Honnet-Porter, E., \& Poulsen, S. (1989). Principles of good practice for combining service and learning. Wingspread Special Report. Racine, WI: The Johnson Foundation.

Howard, J. (1998). Academic service-learning: A counter normative pedagogy. In R. Rhoads and J. Howard (Eds.), Academic service learning: A pedagogy of action and reflection (pp. 21 -30). San Francisco: Jossey-Bass.

Jacoby, B., \& Associates. (1996). Service-learning in higher education: Concepts and practices. San Francisco, CA: Jossey-Bass.

Kaye, C. B. (2004). The complete guide to service learning: Proven, practical ways to engage students in civic responsibility, academic curriculum, and social action. Minneapolis, MN: Free Spirit.

Kenan, S. (2009). The missing dimension of modern education: Values education. Educational Sciences: Theory and Practice, 9(1), 279295.

Kielsmeier, J. C., Neal, M., Schultz, N., \& Leeper, T. J. (2008). Growing to greatness 2008: The state of service-learning project. St. Paul, MN: National Youth Leadership Council.

Kolb, D. A. (1984). Experiential learning: Experience as the source of learning and development. Englewood Cliffs, NJ: Prentice-Hall.

Lawrence, M. N., \& Butler, M. B. (2010). Becoming aware of the challenges of helping students learn: An examination of the nature of learning during a service-learning experience. Teacher Education Quarterly, 37(1), 155-175.

Lemieux, E. M., \& Allen, P. D. (2007). Service learning in social work education: The state of knowledge, pedagogical practicalities, and practice conundrums. Journal of Social Work Education, 43(2), 309-325.

Markus, G., Howard, J., \& King, D. (1993). Integrating community service and classroom instruction enhances learning: Results from an experiment. Educational Evaluation and Policy Analysis, 15(4), 410 - 419.

Metcalf, L. E. (2010). Creating international community service learning experiences in a capstone marketing-projects course. Journal of Marketing Education, 32(2), 155-171.

Moore, D, T. (2000). The relationship between experiential learning research and service-learning research. Michigan Journal of Community Service Learning, Special Issue, 124-128.

Morgan, W., \& Streb, M. (2001). Building citizenship: How quality service-learning develops civic values. Social Science Quarterly, 82(1), 154-169.

Murray, C. E., Lampinen, A., \& Kelley-Soderholm, E. L. (2006). Teaching family systems theory through service-learning. Counsellor Education and Supervision, 46(1), 44-58.

Myers-Lipton, S. (1998). Effect of a comprehensive service-learning program on college students' level of civic responsibility. Teaching Sociology, 26(4), 243-258.

Ottenritter, N. W. (2004). Service learning, social justice, and campus health. Journal of American College Health, 52(4), $189-191$.

Pritchard, F. F., \& Whitehead, G. I. (2004). Serve and learn: Implementing and evaluating service-learning in middle and high schools. Mahwah, NJ: L. Erlbaum Associates.

Quezada, R. L., \& Christopherson R. W. (2005). Adventure-based service learning: University students' self-reflection accounts of service with children. Journal of Experiential Education, 28(1), 1-16.

Rama, D. V., Ravenscroft, S. P., Wolcott, S. K., \& Zlotkowski, E. (2000). Service-learning outcomes: Guidelines for educators and researchers. Issues in Accounting Education, 15(4), 657-692.

Ramaley, J. (2000). Embracing civic responsibility. Retrieved on February 15, 2014, from http://www.aahea.org/articles/march00f2.htm

Rhoads, R. A., \& Howard, J. P. F. (Eds.) (1998). Academic service learning: A pedagogy of action and reflection: New directions for teaching and learning. San Francisco, CA: Jossey-Bass.

Root, S., Anderson, J., Callahan, P., Duckenfield, M., Hill, D., Pickeral, T., \& Wade, R. (2000). Service-learning in teacher education: A handbook. Alma, Ml: Alma College.

Root, S., \& Billig, S. H. (2008). Service-learning as a promising approach to high school civic engagement. In J. Bixby and J. Pace (Eds), Educating democratic citizens in troubled times: Qualitative studies of current efforts. Albany, NY: SUNY Press.

Shumer, R., \& Duckenfield, M. (2004). Service-learning: Engaging students in community-based learning. In F. P. Schargel \& J. Smink (Eds.), Helping students graduate: A strategic approach to dropout prevention (pp. 155-163). Larchmont, NY: Eye on Education. 
Simons, L., \& Cleary, B. (2006).The influence of service learning on students' personal and social development. College Teaching, 54(4), 307-319.

Speck, B. (2001). Why service-learning? New Directions for Higher Education, 114, 3-13.

Stott, K. A., \& Jackson, A. P. (2005). Using service-learning to achieve middle school comprehensive guidance program goals. Professional School Counselling, 9, 156-159.

Strage, A. A. (2000). Service-learning: Enhancing student outcomes in a college-level lecture course. Michigan Journal of Community Service Learning, 7(1), 5-13.

Strupeck, C. D., \& Whitten, D. (2004). Accounting service-learning experiences and the IRS volunteer income tax assistance programme: a teaching note. Accounting Education, 13(1), 101-112.

Stukas, A. A., Worth, K. A., Clary, E. G., \& Snyder, M. (2009). The matching of motivations to affordances in the volunteer environment: An index for assessing the impact of multiple matches on volunteer outcomes. Nonprofit and Voluntary Sector Quarterly, 38(1), 528.

Svoboda Bak, K. (2012). Service-learning now: An education reform strategy with staying power, Colleagues, 9(1), 1-4.

Wren, D. J. (2004). Reaching out, reaching in. Principal Leadership, 5(1), 28-33.

Warburton, J., \& Smith, J. (2003). Out of the generosity of your heart: Are we creating active citizens through compulsory volunteer programs for young people in Australia? Social Policy and Administration, 37(7), 772-786. 